\title{
Effects of bacterial vaginosis and its treatment on sexual functions: A cross-sectional questionnaire study
}

\author{
Bakteriyel vajinoz ve tedavisinin cinsel fonksiyonlar üzerine etkileri: Bir kesitsel anket \\ çalış̧ması
}

Coşkun Şimşir ${ }^{1}$, Bora Coşkun ${ }^{1}$, Buğra Coşkun ${ }^{1}$, Aynur Adeviye Erşahin ${ }^{2}$, Tolga Ecemiş ${ }^{3}$

\begin{abstract}
Aim: To investigate the effects of bacterial vaginosis, which is the most frequent vaginal infection in women, and its treatment on sexual functions.

Methods: Patients who had applied to our gynecology outpatient clinic with bacterial vaginosis based on the culture results were included in this observational questionnaire study. Patients with an accompanying disease possibly resulting in sexual dysfunction and those with vaginitis etiology other than bacterial vaginosis were excluded from the study. Patients were asked to fill the Female Sexual Function Index (FSFI) during the diagnosis of bacterial vaginosis and 1 month later than the treatment.

Results: Seventy-two patients who had applied to our outpatient clinic between January 2018 and January 2019 and who met the study criteria were included in this study. Statistically significant improvement was found in post-treatment orgasm and pain scores and in total FSFI scores of the patients upon comparison of FSFI scores of patients before and after the treatment $(p<0.001)$. However, no statistically significant differences were found in sexual desire, arousal, lubricity and general satisfaction scores before and after the treatment ( $p>0.05$ for all).

Conclusion: It was found that sexual dysfunction was more common in patients with bacterial vaginosis and improvement was seen in some sexual functions with treatment.
\end{abstract}

Keywords: Bacterial vaginosis, sexual dysfunction, Female Sexual Function Index

Öz

Amaç: Kadınlarda en sık görülen vajinal enfeksiyon olan bakteriyel vajinozun ve tedavisinin cinsel fonksiyonlara olan etkilerini araştırmak.

Yöntemler: Ocak 2018-Ocak 2019 tarihleri arasında jinekoloji polikliniğimizde kültür sonuçlarına dayanarak bakteri vajinoz tanısı alan hastalar bu gözlemsel anket çalışmasına dahil edildi. Eşlik eden bir hastalığı olan ve muhtemelen cinsel işlev bozukluğu olan hastalar ile bakteriyel vajinoz dışındaki vajinit etiyolojisi olanlar çalışma dışı bırakıldı. Hastalara bakteri vajinoz teşhisi sırasında ve tedaviden 1 ay sonra Kadın Cinsel İşlev İndeksi (FSFI) anketi uygulandı.

Bulgular: Çalışma kriterlerini karşılayan 75 hasta çalışmaya dahil edildi. FSFI skorlarının karşılaştırılmasında tedavi sonrası orgasm, ağrı skorları ve toplam FSFI skorlarında istatistiksel olarak anlamlı düzelme saptandı $(\mathrm{p}<0,001)$. Ancak, tedavi öncesi ve sonrasında cinsel istek, uyarılma, kayganlık ve genel memnuniyet skorlarında istatistiksel olarak anlamlı bir fark bulunmadı (hepsi için $\mathrm{p}>0,05$ ).

Sonuç: Bakteriyel vajinozlu hastalarda cinsel işlev bozukluğunun daha yaygın olduğu ve tedaviyle bazı cinsel işlevlerde düzelme olduğu tespit edildi.

Anahtar Sözcükler: Bakteriyel vajinoz, cinsel işlev bozukluğu, Kadın Cinsel İşlev İndeksi
${ }^{1}$ Liv Hospital Ankara, Department of Obstetrics and Gynecology, Ankara, Turkey.

2 Bahçeşehir University, Faculty of Medicine, Department of Obstetrics and Gynecology, İstanbul, Turkey.

${ }^{3}$ Private Clinic, Ankara, Turkey.

Ethics Committee Approval: The study wass approved by the local ethical authority (11.01.2018-2018/04).

Etik Kurul Onayı: Çalışma lokal etik komite tarafindan onaylanmıştır (11.01.2018-2018/04).

Conflict of Interest: No conflict of interest was declared by the authors.

Çıkar Çatışması: Yazarlar çıkar çatışması bildirmemişlerdir.

Financial Disclosure: The authors declared that this study has received no financial support.

Finansal Destek: Yazarlar bu çalışma için finansal destek almadıklarını beyan etmişlerdir.

Geliş Tarihi / Received: 01.07.2019

Kabul Tarihi / Accepted: 22.07.2019

Yayın Tarihi / Published: 01.08.2019

Sorumlu yazar / Corresponding author:

Buğra Coşkun

Adres/Address: Liv Hospital Ankara, Department of Obstetrics and Gynecology, Ankara, Turkey. e-posta: drbugracoskun@gmail.com

Tel/Phone: +90 5323501404

Copyright (C) ACEM 


\section{Introduction}

The most frequent vaginal infection in the reproduction period is bacterial vaginosis [1]. The most common causative organism is Gardnerella vaginalis, which is found in the normal flora and causes vaginal infection in case of changes in the flora. The same picture can be seen with many other anaerobic bacteria with Bacteroides and M. hominis in the first place [2].

Almost half of patients with bacterial vaginosis are asymptomatic. While the most frequent complaints at presentation are vaginal discharge and bad odor that irritate the couple during sexual intercourse, complaints about the sense of disgust and lack of pleasure from the intercourse are mentioned more when the anamnesis is deepened somehow. This in turn affects the sexual lives of patients and can result in sexual dysfunction in patients [3].

Sexual dysfunction in women can be related to several factors including psychological, physiological and individual characteristics [4]. Conditions such as vaginal infection also result in sexual dysfunction leading to self-confidence problems and emotional stress, which in turn has negative effects on the quality of life [5]. Only half of these women apply to a doctor for a solution [6]. Sexual dysfunction in any member of the married couple will also impair the integrity of the marital union. Therefore, finding out the cause of sexual dysfunction in such individuals and its treatment is important.

In our study, we aimed at investigating if the sexual dysfunction related to bacterial vaginosis would improve with treatment.

\section{Material and methods}

Patients diagnosed with bacterial vaginosis among the patients who had applied to the Gynecology Outpatient Clinic of Ankara Liv Hospital were interrogated in our scaled and stratified survey. We have carried out after obtaining the approval of the Ethical Committee of Liv Hospital Ankara with the date of January/11/2018 and number of 2018/004.

Patients with accompanying diseases that could cause sexual dysfunction such as vaginal candidiasis, pelvic lesions, previous known psychological disorders, neuromuscular diseases, hormonal problems or vascular insufficiency were excluded from the study. Patients using antidepressants, antipsychotics, antihypertensive medicines, anticholinergic drugs, antacids or oral contraceptives were exclusives from the study.

Of the two hundred and eight patients diagnosed with bacterial vaginosis between the determined dates, 120 gave their consents and met the study conditions were included in the study and were required to fill the FSFI questionnaire. Following the bacterial vaginosis treatment, $72 \%$ of patients came back for control 1 month later and filled the FSFI questionnaire again (Figure 1).

Forty-two patients refusing to fill the questionnaire out of 162 meeting the study conditions were not included in the study. Helsinki Declaration Criteria were taken into consideration when implementing the study [7]. Patients included in the study were informed about the study as required, and their written consents were obtained.

Age, number of pregnancies, parity, abortion, body mass index $\left(\mathrm{kg} / \mathrm{m}^{2}\right)$, level of education, profession, smoking and alcohol use of patients were interrogated. Patients were asked to fill the FSFI questionnaire including 19 items before and after the bacterial vaginosis treatment. Metronidazole $500 \mathrm{mg} 2 \times 1$ oral preparations were administered for the treatment of patients.

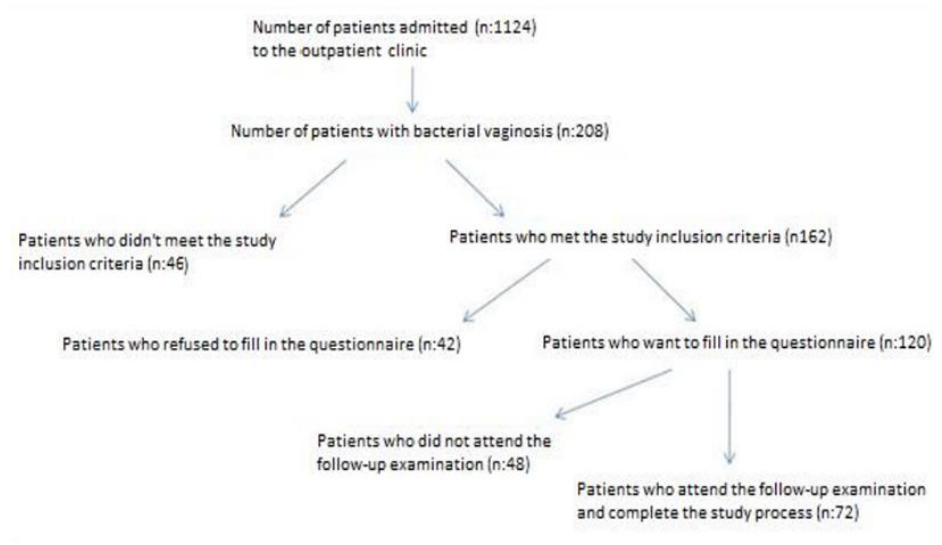

Figure 1. Study flow chart.

\section{Female Sexual Function Index (FSFI)}

FSFI questionnaire is a questionnaire with 19 items developed by Rosen and colleagues developed in 2000 to be used to evaluate the sexual functions [8]. It evaluates the sexual life within the last four weeks. The questionnaire interrogates the parameters related to sexual desire (items 1 and 2), arousal (items 3-6), lubrication (items 7-10), orgasm (items 11-13), satisfaction in general (items 14-16) and pain (items 17-19), respectively.

The first 2 items are scored between 1 and 5 , while the remaining items are scored between 0 and 5 . The greatest score can be 95 , and the lowest score can be 2 . Scores obtained in each domain are multiplied by coefficients homogenizing the effects (0.6 for items 1 and 2; 0.3 for items 3 to 10 ; and 0.2 for items 11 to 19). Total FSFI scores however, are calculated by summing each score in the homogenized domain. Total FSFI scores range between 1.2 and 36. Higher scores define better sexual lives. Total FSFI score $\leq 26.5$ is defined as sexual dysfunction. This questionnaire was approved for the Turkish population also in 2005 [9].

\section{Statistical Analysis}

Data analyses were carried out by using the SPSS 23.0 program. Descriptive data and frequencies were calculated with the help of the computer. While the continuous variables were expressed as mean \pm standard deviation and median (minimummaximum), categorical variables were expressed as number and percentage. Kolmogorov-Smirnov test was used for the normality test. Whether or not there are any differences between the FSFI scores before and after the treatment was analyzed with t-test. $\mathrm{P}$ value $<0.05$ was accepted as the level of statistical significance.

\section{Results}

Bacterial vaginosis was detected in 208 (18.5\%) of 1124 patients admitted to the outpatient clinic during the study period. The mean age of patients was 27.7 years, and the mean body mass index was $25.2 \mathrm{~kg} / \mathrm{m} 2$. Majority of patients were graduates of high school $(29.2 \%)$ and were working in some job (65.3\%). Rate of smoking was $38.9 \%$ while alcohol consumption rate was $11.1 \%$ (Table 1 ).

Comparison of FSFI scores of patients before and after treatment showed statistically significant improvement in pain, orgasm, and total FSFI scores $(\mathrm{p}<0.001)$. However, no statistically significant differences were found in sexual desire, arousal, lubrication and general satisfaction scores $(p>0.001$ for all) (Table 2).

Table 1. Demographic findings. 


\begin{tabular}{|c|c|c|}
\hline \multicolumn{2}{|l|}{ Variable } & $\mathrm{n}(\mathrm{N}=72)$ \\
\hline \multicolumn{2}{|c|}{ Age $(\text { years })^{\beta}$} & $27.7 \pm 6.3$ \\
\hline \multicolumn{2}{|c|}{ Body mass index $\left(\mathrm{kg} / \mathrm{m}^{2}\right)^{\beta}$} & $25.2 \pm 3.5$ \\
\hline \multicolumn{2}{|c|}{ Gravida $¥$} & $2(0-4)$ \\
\hline \multicolumn{2}{|l|}{ Parity ${ }^{\ddagger}$} & $1(0-3)$ \\
\hline \multicolumn{2}{|c|}{ Abortions ${ }^{¥}$} & $1(0-2)$ \\
\hline \multicolumn{3}{|c|}{ Occupation $^{\mu}$} \\
\hline & Active & $47(65.3)$ \\
\hline & Housewife & $25(34.7)$ \\
\hline \multicolumn{3}{|c|}{ Level of education ${ }^{\mu}$} \\
\hline & No & $8(11.1)$ \\
\hline & Primary education & $19(26.4)$ \\
\hline & Secondary & $14(19.4)$ \\
\hline & High school & $21(29.2)$ \\
\hline & High education & $10(13.9)$ \\
\hline \multicolumn{3}{|l|}{ Smoking ${ }^{\mu}$} \\
\hline & Yes & $28(38.9)$ \\
\hline & No & $44(61.1)$ \\
\hline \multicolumn{3}{|l|}{ Alcohol $^{\mu}$} \\
\hline & Yes & $8(11.1)$ \\
\hline & No & 64 (88.9) \\
\hline
\end{tabular}

${ }^{\beta}$ :mean \pm standard deviation, ${ }^{*}$ :median (range), ${ }^{\mu}$ :number (percentage).

Table 2. Comparison of pre- and post-treatment FSFI Scores.

\begin{tabular}{llll} 
Parameter & $\begin{array}{l}\text { Before } \\
\text { treatment }\end{array}$ & After treatment & $\mathrm{p}$ \\
\hline Desire $^{\beta}$ & $2.66 \pm 1.30$ & $3.40 \pm 1.78$ & 0.082 \\
Excitement $^{\beta}$ & $1.93 \pm 1.20$ & $2.98 \pm 1.47$ & 0.065 \\
Lubrication $^{\beta}$ & $1.87 \pm 1.13$ & $3.30 \pm 1.15$ & 0.058 \\
Orgasm $^{\beta}$ & $2.12 \pm 1.20$ & $3.64 \pm 1.22$ & $<0.001$ \\
Overall $^{\beta}$ & $1.93 \pm 1.23$ & $2.88 \pm 1.16$ & 0.062 \\
satisfaction $^{\beta}$ & $1.58 \pm 1.28$ & $3.21 \pm 1.38$ & $<0.001$ \\
Pain $^{\beta}$ & $11.62 \pm 5.38$ & $18.62 \pm 5.66$ & $<0.001$ \\
FSFI total & $\beta$ & &
\end{tabular}

B:mean \pm standard deviation.

\section{Discussion}

Sexual dysfunction is an important health problem that involves both females and males and affects feelings and attitudes of the couple against each other. However, too few couples verbalizes this problem and apply to a specialist for treatment. Even, they abstain to talk to each other with the idea that they could be misunderstood [10]. In particular, sexual dysfunction in women reduces their self-confidence, cause psychological burn-out and lower their quality of life $[11,12]$.

Sexual function can deteriorate in women together with advancing age, and almost half of women can face this problem in any period of their lives [13]. While there are no very comprehensive studies in our country, frequency of sexual dysfunction in women was found as $46.9 \%$ in a study conducted by Çayan and colleagues [14]. In another country carried out in our country on 518 female participants by Öksüz and colleagues, sexual dysfunction was found with a frequency of $48.3 \%$ [15]. With the reason that sexual dysfunction is common in the society, it is a health problem that should be addressed and attached importance to.

We conducted an FSFI questionnaire study at the baseline and in month 1 following the treatment in patients diagnosed with bacterial vaginosis and other causes of sexual dysfunction have been eliminated. We found the incidence of bacterial vaginosis as $18.5 \%$. This rate was found between $10 \%$ and $20 \%$ in most of the studies [16]. We also found reduction in dyspareunia and increase in the frequency of orgasm. We also found marked improvement in total FSFI scores. In a questionanswer study carried out by Bilardi and colleagues on 35 patients through face-to-face interviews or phone calls, it was found sexual life was affected in recurring bacterial vaginosis patients. It was concluded in this study that bacterial vaginosis affects the emotional, physical, social and sexual lives of patients in different levels. Patients have stated that they feel dirty and bad, were ashamed of their condition and avoided sexual intercourse [17]. In another study carried out Donders and colleagues, it was stated that abnormal vaginal microbiome caused vulvodynia, the most frequent cause was bacterial vaginosis, and this in turn caused sexual dysfunction in patients [18].

It has been shown that sexual dysfunction in women is much more complex than in men, and sexual dysfunction has many causes [19]. Both because the female sexual functions are more complex in structure and women avoid to discuss this subject, treatment of sexual dysfunction is difficult [20]. A portion of patients think that their condition is a part of their normal lives, and discharge is physiologic, because discharge is not always vexing. Sometimes discharge is seen only in small amounts that only smudges on the vaginal walls and labia, it can be in excessive amounts that will lead the patient to make a visit for examination and to accumulate in the posterior fornix [3].

In case of vaginal discharge, which is one of the reasons of visits of patients to gynecology outpatient clinics, dyspareunia and other sexual dysfunctions related to vaginal irritation are also seen commonly. In particular, the spoiled fish odor, which is unique for bacterial vaginosis, can cause sexual dysfunction in the spouse like in the female. In fact, bacterial vaginosis can be treated with a very simple antibiotic regime without even a necessity for the treatment of the spouse and the sexual life of the couple can return to normal. In case of neglected bacterial vaginosis however, this sexual dysfunction process will be elongated, drags the spouses even more apart, and affect their psychologica statuses in time. However, although delayed bacterial vaginosis treatment can eliminate the organic cause, spouses can need psychotherapy for their sexual dysfunctions.

Patients complain about bleeding and bad odor during the sexual intercourse, they are ashamed of this and create excuses to avoid intercourse. This leads to problems between the spouses. Therefore, level of awareness about the fact that bacterial vaginosis is a treatable disease, and efforts to increases their quality of life with treatment must be supported.

Although effectiveness of the FSFI questionnaire in displaying the sexual dysfunction is reliable, after all, it is based on the subjective answers of patients. Considering the conditions of the country we live in; women avoid to answer the questions related to their sexual lives. In our study also, number of women who meet the inclusion criteria and refused to participate is rather high. Our results seen support with studies based on larger patient populations.

\section{References}

1. Verstraelen H, Swidsinski A. The biofilm in bacterial vaginosis: implications for epidemiology, diagnosis and treatment. Current Opinion Infectious Diseases. 2013;26:86-9.

2. Li M, Li L, Wang R, Yan SM, Ma XY, Jiang S, et al. Prevalence and risk factors for bacterial vaginosis and cervicitis among 511 female workers attending gynecological examination in Changchun, China. Taiwan J Obstet Gynecol. 2019;58:385-9.

3. AlAwlaqi A, Amor H, Hammadeh ME. Role of hormones in hypoactive sexual desire disorder and current treatment. J Turk Ger Gynecol Assoc. 2017;18:210-8.

4. Salonia A, Munarriz RM, Naspro R, Nappi RE, Briganti A, Chionna R et al. Women's sexual dysfunction: a pathophysiological review. BJU Int. 2004;93:1156-64.

5. Clayton AH, Valladares Juarez EM. Female Sexual Dysfunction. Med Clin North Am. 2019;103:681-98.

6. Pauls RN, Kleeman SD, Karram MM. Female sexual dysfunction: principles of diagnosis and therapy. Obstet Gynecol Surv. 2005;60:196205. 
7. Krleža-Jerić K, Lemmens T. 7th Revision of the Declaration of Helsinki: Good News for the Transparency of Clinical Trials. Croat Med J. 2009;50:105-10.

8. Rosen R, Brown C, Heiman J, Leiblum S, Meston C, Shabsigh R, et al. The Female Sexual Function Index (FSFI): a multidimensional selfreport instrument for the assessment of female sexual function. J Sex Marital Ther. 2000;26:191-208.

9. Aygin D, Eti Aslan F. The Turkish Adaptation of The Female Sexual Function Index, Turkey Clinics J Med. 2005;25:393-9.

10. da Costa CKL, Spyrides MHC, de Sousa MBC. Consistency of three different questionnaires for evaluating sexual function in healthy young women. BMC Womens Health. 2018;18:204.

11. Thakar R. Review of current status of female sexual dysfunction evaluation in urogynecology. Int Urogynecol J Pelvic Floor Dysfunct. 2009;20 Suppl 1:S27-31.

12. McCool ME, Theurich MA, Apfelbacher C. Prevalence and predictors of female sexual dysfunction: a protocol for a systematic review. Syst Rev. 2014;3:75.

13. Kingsberg S, Althof SE. Evaluation and treatment of female sexual disorders. Int Urogynecol J Pelvic Floor Dysfunct. 2009;20 Suppl 1:S33-43.

14. Cayan S, Akbay E, Bozlu M, Canpolat B, Acar D, Ulusoy E. The prevalence of female sexual dysfunction and potential risk factors that may impair sexual function in Turkish women. Urol Int. 2004;72:52-7.

15. Oksuz E, Malhan S. Prevalence and risk factors for female sexual dysfunction in Turkish women. J Urol. 2006;175:654-8.

16. Bilardi JE, Walker S, Temple-Smith M, McNair R, Mooney-Somers J, Bellhouse $\mathrm{C}$, et al. The burden of bacterial vaginosis: women's experience of the physical, emotional, sexual and social impact of living with recurrent bacterial vaginosis. PLoS One. 2013;8:e74378.

17. Frølund M, Falk L, Ahrens P, Jensen JS. Detection of ureaplasmas and bacterial vaginosis associated bacteria and their association with nongonococcal urethritis in men. PLoS One. 2019;14:e0214425.

18. Donders GGG, Bellen G, Ruban KS. Abnormal vaginal microbioma is associated with severity of localized provoked vulvodynia. Role of aerobic vaginitis and Candida in the pathogenesis of vulvodynia. Eur $\mathbf{J}$ Clin Microbiol Infect Dis. 2018;37:1679-85.

19. Levin RJ. The human sexual response-Similarities and differences in the anatomy and function of male and female genitalia. In: Janssen E, (Ed). The psychophysiology of sex. Bloomington: Indiana University Press; 2007. pp.35-56.

20. Lo SS, Kok WM. Prevalence and Risk Factors for Sexual Problems and Distress in Chinese Unmarried Young Women: An Observational Study. J Sex Med. 2018;15:1620-8. 